\title{
LCT in Developing, Lower and Middle Income and Developed Countries
}

\section{OPEN ACCESS}

Manuscript ID:

EDU-2021-09033784

Volume: 9

Issue: 3

Month: June

Year: 2021

P-ISSN: $2320-2653$

E-ISSN: 2582-1334

Received: 24.02.2021

Accepted: 15.04.2021

Published: 01.06.2021

Citation:

Shah, Rajendra Kumar.

"LCT in Developing,

Lower and Middle Income and Developed Countries." Shanlax International Journal of Education, vol. 9 , no. 3, 2021, pp. $110-126$.

DOI:

https://doi.org/10.34293/ education.v9i3.3784

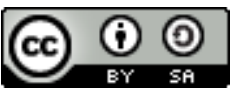

This work is licensed under a Creative Commons Attribution-ShareAlike 4.0 International License

\author{
Rajendra Kumar Shah \\ Associate Professor, Tribhuvan University (Sanothimi Campus), Bhaktapur, Nepal \\ https://orcid.org/0000-0003-0533-1338
}

\begin{abstract}
LCT has been a recurrent theme in many national educational policies in the global South and has had wide donor support through aid programs and smaller projects and localized innovations. However, the history of the implementation of LCT in different contexts is riddled with stories of failures, grand and small. This article provides an overview of the four major topics-context of LCT, LCT in lower and middle-income countries, LCT in the developing and LCT in the developed countries. The major aim of the article is to explore the status of LCT in underdeveloped, to develop and developed countries. For this purpose, I searched scholarly and online databases (Google Scholar, JSTOR, Proquest) that focus on LCT and related policies, trends, and issues in various countries. I used search terms associated with the various LCT topics in lower and middleincome countries, LCT in developing countries, and LCT in the developed countries. LCT is a traveling policy that has been endorsed by international agencies, national governments, and local innovators. As a globally traveling policy and practice, prescriptions and innovations regarding LCT are often found in contexts where it is culturally new and where the realities of educational governance and resources for schools have not historically accommodated it. Though there are several successful LCT projects, these are too few compared to the magnitude of the failures of the approach in developing countries. In a number of these countries, attempts at transforming traditional classrooms into LCT classrooms have failed. In a recent analysis of the research on LCT implementation, it was evident that the history of the implementation of LCT in different contexts is riddled with stories of failures, grand and small. Across a wide range of developing country contexts, the reports of tissue rejection as teachers and learners struggle to make the paradigm shift far outnumbered the stories of successful transitions from the pedagogies in place towards LCT.

Keywords: Learner-centred teaching, Learning, Lower and middle-income countries, Developing countries, Developed countries
\end{abstract}

\section{Context of LCT}

Learner-centered teaching (LCT) is a traveling policy (Ozga \& Jones, 2006) that has been endorsed by international agencies, national governments, and local innovators. Promoters of this LCT tradition refer to theories and evidence from cognitive psychology, claiming that all learners can benefit from improved processes and outcomes. Beyond the benefits to the individual, however, lies a set of assumptions about LCT as a foundation for the building of democratic citizens and societies and the development of a skilled population ready for the knowledge economies of the future. These promises have been questioned by critics who doubt that it is appropriate in all cultural and resource contexts. There is considerable evidence in the global South of perennial problems of implementation (Schweisfurth, 2011). Though there are several successful LCT projects in science classrooms in Africa (Adesoji, 1995; Agbayewa, 1996; Akinbobola, 2004), these are too few compared to the magnitude of the failures the approach in developing countries. In a number of these countries, attempts at transforming traditional classrooms into LCT classrooms have failed. 
As a globally traveling policy and practice, prescriptions and innovations regarding LCT are often found in contexts where it is culturally new and where the realities of educational governance and resources for schools have not historically accommodated it. In a recent analysis of the research on LCT implementation reported in an international journal on education and development (Schweisfurth, 2011), it was evident that 'the history of the implementation of LCT in different contexts is riddled with stories of failures grand and small' (Schweisfurth, 2011). Across a wide range of developing country contexts, the reports of tissue rejection (Harley, et al., 2000) as teachers and learners struggle to make the paradigm shift (Nakabugo and Sieborger, 2001; Tabulawa, 2003) far outnumbered the stories of successful transitions from the pedagogies in place towards LCT.

Schweisfurth (2011) evaluated some 72 research studies over three decades and found that "the history of the implementation of LCT in different contexts is riddled with stories of failures grand and small.' Some have even described LCT as tissue rejection (Harley, et al., 2000). Teachers were unable to make the paradigm shift for many reasons that are detailed later in the chapter. The case of South Africa is interesting because it is one of the rare African countries where LCT is officially promoted and supported. The history of the implementation of LCT in different contexts is riddled with stories of failures grand and small (Schweisfurth, 2011). Experiences from both Western and developing countries seem to point us to stories of challenge or even failure in the implementation of LCT on a large scale. Even in the UK, LCT has not been without controversy, drawing waves of criticism about declining standards of literacy, numeracy, and behavior perceived to be resulting from LCT reforms in recent decades (Schweisfurth, 2013). In both the UK and the US, the implementation of LCT has been uneven, and LCT in its pure, idealized form has not been practiced on a systemic scale anywhere globally, beyond isolated classrooms or schools, often in independent private schools. This fact, along with the numerous stories of failure of national LCT implementation efforts in developing countries, leads Thompson (2012) to argue pragmatically that LCT should not be advocated for large-scale public sector reforms in under-resourced developing countries, but only in small-scale consortiums of private schools possessing the abundant resources needed for LCT's success. However, this proposal raises other equity concerns of whether the emancipatory ideals of LCT are compatible with attempts to restrict it to only an elite urban minority. At the same time, a separate pedagogy of arguably inferior quality is designated for the rural masses.

\section{Methods and Materials}

The major aim of the article is to explore the status of LCT in underdeveloped, to develop and developed countries. For this purpose, I searched scholarly and online databases (Google Scholar, JSTOR, Proquest) that focus on the status of LCT and related policies, trends, and issues in various countries. I used search terms associated with the various LCT topics in lower and middle-income countries, LCT in the developing countries, and LCT in the developed countries. This study is completely based on the secondary sources of the data.

\section{LCT in Lower and Middle Income Countries}

In a survey of 102 video-recorded lessons in Kenya, as a baseline data set to an LCT-oriented intervention, Hardman et al. (2009) describe pedagogical norms which are fairly typical of much of Sub-Saharan Africa and other parts of the developing world: lessons dominated by lecturing, with occasional question-and-answer, copying, and individual written exercises; mainly closed questions being asked (98\%); pupil questioning rare; boys twice as likely to be asked a question by the teacher as girls; more than 33\% choral answers; only $3 \%$ of lessons including pair or group work; and a traditional, desks-in-rows classroom layout in $96 \%$ of lessons. If there is truth to the benefits of LCT as laid out in the narratives above, then most learners in poorer parts of the world are not experiencing it and introducing LCT through policy reform does not seem readily able to change that. Firstly, the policy process itself can be a barrier, as policy messages can be difficult for teachers to understand, can be contradictory, or the process may not be supported in different parts of the system (teacher education 
and inspection, for example, can work against LCT if they are not 'on message'). A classic and recurrent policy contradiction is to promote LCT pedagogy in situations where high-stakes examinations which test fixed knowledge drive teacher, student and parent motivation. As a student, if your future education and career depend on examination results, the openended exploration of content not likely to be tested will seem like a luxury, and teachers will teach to examinations to meet students' needs and to protect their reputations. This is the case in a wide range of contexts where policy has pointed both to LCT and tight assessment frameworks, South Africa and China being prevalent examples. Furthermore, in contexts of fragility, the policy process is complicated by a range of factors from poor infrastructure to corruption to prioritization of survival needs, all of which make the reach of government initiatives problematic.

Secondly, material resource shortages are often cited by teachers as a major issue in terms of their ability to meet policy demands or other encouragements in LCT directions. They note the physical environment, class size and teaching materials as impediments to adopting LCT pedagogical approaches. While not belittling such concerns, it is noteworthy that in placing these at the forefront of their barriers, teachers place the problem outside of themselves; however, they also stress the importance of recognition and appreciation in motivating them to try new pedagogical approaches (VSO, 2002). Human resources are a significant part of the equation and of course, motivation is an important dimension of this. Teacher motivation is problematic across much of the developing world. Working conditions and salaries do not make teaching a first-choice profession, and where respect from the government, the press and local communities cannot be taken for granted. In the poorest countries and the poorest and most remote parts of middle and low-income countries, teachers are often untrained or undereducated. Many teachers are expected to work in a language of instruction-usually a colonial language and usually English-in, which they are not comfortably fluent. This has been shown to make them more cautious in classroom dialogue and they tend to ask closed questions. They use drills as strategies for ensuring that the discussion does not slip beyond their comprehension or comfort zone (Brock-Utne \& Holmarsdottier, 2004) on Tanzania and South Africa. As an additional important dimension of the human resource base, teacher professional identity is a highly context-specific phenomenon. Still, in many parts of the developing world, the reflective and autonomous practitioner embedded in developed forms of LCT is not nurtured.

Culture shapes all of these phenomena and interacts profoundly with teacher-learner relationships and classroom behavioral norms. Two of Hofstede's (2003) cultural continua create a helpful language here. Some cultures have greater power distance between those with less and more power in a society, such as teachers and students: it is alien in such countries to have a close and familiar relationship with a teacher or to question his or her wisdom. In collectivist cultures, the integration of people into a strong, cohesive in-group is the norm. The individualizing of curricula rather than a focus on the class collective may seem inappropriate. Both of these have major implications for LCT as it is widely conceived. Sternberg (2007) notes that one of the universal lessons of learning is that being taught in culturally-appropriate ways raises achievement, raising an interesting conundrum for those seeking to introduce LCT into high power distance and collectivist societies.

There are, of course, many rich contextual details which illustrate, nuance, or correct these generalizations, and the book (Schweisfurth, 2013) develops five case studies that explore these. There are also positive stories of LCT implementation, usually where there has been joined-up thinking across the whole education sector, from pre-service training through school management through supervision, inspection and support regimes through in-service professional development. These all demand, however, a policy and practice context which is coherent in itself, well-resourced on the human front, and in which there is a critical mass of actors already deeply familiar with the demands, joys and practices of LCT, rather than rhetorical prescriptions. They also raise substantial questions about the extent to which LCT as moves in its traveling manifestations is a desirable and feasible policy and practice in all contexts, and some writers 
have concluded that it is not appropriate for some environments (Guthrie, 2011) where investment in improving tried-and-tested formal pedagogies offers a more promising return on investment.

\section{LCT in the Developing World}

LCT has been increasingly encouraged across nations, particularly in developing nations, under the sponsorship of international aid agencies. In the 1990s, many aid agencies from Canada, the US, UK, Denmark and Norway advocated LCT to support democratization, funded LCT-oriented projects, and sometimes prescribed LCT as a condition for structural adjustment packages (Tabulawa, 2003). Schweisfurth (2013) points to the powerful aura that has begun to surround LCT, increasingly enshrined in international agreements at a supranational level. The UN Convention on the Rights of the Child guarantees children the right to access modern teaching methods. At the same time, international initiatives such as Education for All (EFA) tend to assume that improving education quality implies moving towards 'active and participatory approaches' (UNESCO, 1990). LCT is also increasingly promoted by multilateral organizations; UNICEF's Child-Friendly Schools see a key marker of quality education as the extent to which LCT methods are embraced.

To understand the rationale driving this global promotion of LCT as a policy panacea, Schweisfurth (2013) offers a useful categorization of three broad lines of argument typically used by LCT's proponents. The first is the cognitive argument that individuals learn better when given initiative and freedom in structuring their learning with help from a facilitator. The second is an emancipatory perspective, highlighting LCT's potential to free people from oppressive forms of control that seek to stifle independent thinking and critical questioning. The third perspective, which would be opposed by the second, views LCT as appropriate preparation for building the flexible, self-directed learning needed for modern working life in changing economic world order. However, Schweisfurth points out, all three strands of argument have been rooted more in rhetoric than in evidence. The second and third strands do not even attempt to draw from the evidence, using a rights-based perspective to assume its justification in the case of the second or requiring essentially a leap of faith in the third. Even in the cognitive strand, the few studies that have attempted to establish a link between LCT and improved learning outcomes remain inconclusive.

Several critics have questioned whether LCT should continue being recommended as a policy choice worldwide. One critique is the apparent lack of conclusive evidence for LCT resulting in improved academic learning outcomes (Alexander, 2000; O'Sullivan, 2006; Tabulawa, 2003). While some studies show a correlation between the two (Cornelius-White, 2007), these findings are sometimes questionable due to small sample sizes and challenges in methodology and research design. The second line of critique relates to operational complexities that ultimately defy simple binaries of teacher-centered teaching (TCT) and learnercentered teaching (LCT) as discrete categories. On the one hand, learners are not necessarily passive in TCT (Vavrus, 2009).

Conversely, LCT classrooms do not imply passive teachers that let students decide what to do, when and how; the teacher remains in authority and an authority on the subject matter. Van Harmelen (1998) critiques the assumption that all transmission teaching or factual recall should be discarded, which ignores their important value in the educational process. What often occurs in practice is more complex hybridity of mixed approaches within a continuum of more and less LCT practice (Schweisfurth, 2011; Thompson, 2012; Vavrus, 2009). Both Barrett (2007) and Sriprakash (2012) identify teachers in Tanzania and India as working with a mixed palette of both TCT and LCT techniques and ideas.

Thompson is not the only one to question the appropriateness of LCT for developing countries, based on various constraints in this context that may render LCT inappropriate. These include limited resources, incompatible examination and curricular systems, substandard teacher training, unrealistic policy expectations, or differences in cultural models that may conflict with LCT assumptions. This has led some to question the underlying political agendas and global hegemonies driving international agencies to export LCT as a one-size-fits-all, 
decontextualized 'best practice,' despite numerous stories of failure (O'Sullivan, 2006; Vavrus, 2009). Critics suggest that the adoption of " models of LCT in developing countries amounts to neo-colonialism, denouncing the unequal and unidirectional flow of Eurocentric knowledge to undeveloped countries that have characterized international education, and the consequent marginalization of indigenous knowledge systems within the global discourse (Kanu, 2005; O’Donoghue, 1994). Tabulawa (2003) goes to the extreme of labeling LCT a colonizing, domesticating pedagogy being pushed by international aid agencies purely for political and ideological rather than educational reasons. $\mathrm{He}$ argues that LCT is part of a design by aid agencies aimed not at improving learning but at eroding traditional authoritarian structures and promoting social values associated with liberal democracy, ultimately intended to facilitate the penetration of capitalist ideology in developing nations under the guise of democratization-'representing a process of Westernisation disguised as quality and effective teaching'.

Even if one does not go as far as embracing Tabulawa's conspiracy theory, such critiques do raise the question of whether LCT is indeed a 'Western' construct that is inappropriate in nonWestern contexts such as India. Schweisfurth (2011) aptly questions whether a postcolonial perspective implies that LCT should be rejected as a form of imperialism or embraced as a potential liberator? Should LCT give way to traditional cultures, or can LCT itself be used to challenge and steer prevailing cultural attitudes? In his critique of LCT, Tabulawa seems to uncritically reject LCT values such as open-mindedness and tolerance simply because they are associated with democratic systems, and thus inherently Western and warranting rejectionwhich is an unsubstantiated line of reasoning. The complicated history of colonization means that there is no easy way to delineate what elements of culture and pedagogy are indigenous and foreign. Postcolonial theory blurs this line between local and colonial, reminding us that indigenous culture is not a static closed system but is itself heterogeneous, embroiled in modernist discourses, and infused by relations of power and inequality. Indigenous cultural beliefs cannot be blindly condoned to the rejection of anything Western, particularly if they are detrimental to children's learning, a violation of children's rights, or being used to perpetuate the oppression of marginalized communities. Rather than blindly rejecting one or the other, traditional cultures as well as Western-originating progressive pedagogies need to be critically examined to determine what pedagogical approaches are most appropriate for supporting successful learning and for challenging oppressive forces within the Indian context.

LCT in developing countries has been the focus of discussion since the 1990s. LCT in Asia, including Nepal, Africa, and other developing countries, has been supported by international aid organizations such as UN agencies, UNESCO and UNICEF. Often this assistance is provided under the rationale of enhancing participation in schooling in line with the Millennium Development Goals (MDGs) and Education for All (EFA) (Mtika \& Gates, 2010; Serbessa, 2006). Schweisfurth (2011) emphasizes that some aid agencies view LCT as a policy panacea... to address a myriad of social problems in the developing world. Accordingly, International aid agencies and institutions such as the World Bank and the International Monetary Fund have prescribed the introduction of LCT through educational projects in developing countries, showing their preference and support for Western liberal democracy. Nykiel-Herbert (2004) notes that LCT has spread in developing countries, making a transition to democracy, perhaps because it promises intellectual liberation and emancipates from traditional approaches that are considered oppressive. LCT might also be considered democratic in that it calls for an equal relationship between teachers and students.

Nykiel-Herbert (2004) critiques the role that aid agencies play in promoting LCT as a one-size-fitsall pedagogical approach, which works effectively in any setting. Similarly, Tabulawa (2003, cited in Altinyelken, 2011) argues that if pedagogical practices are converging around the world (at least in the official curriculum), it is because a certain pedagogical approach is in the interests of powerful states or international organizations'. Guthrie (1990, 
cited in Tabulawa, 2003) similarly suggests that LCT represents a process of westernization with its political and economic meanings. Such discussions emphasize the interconnected nature of pedagogy, politics and ideology. Whatever the reasons for implementing such approaches in developing country contexts, 'the history of the implementation of LCT in different contexts is riddled with stories of failures grand and small' Schweisfurth (2011). The challenges in implementing LCT in developing countries include policy issues, cultural factors, professional capacity, teachers' beliefs, and parents' and students' attitudes towards LCT.

According to Tabulawa (2003), aid agencies justify their promotion of such pedagogy in 'benign and apolitical terms', emphasizing the efficacy of LCT in cognitive/educational terms. In the same vein, LCT ideas have been introduced in teachertraining programs and school reforms in many parts of Africa and Asia with the intention of creating more child-friendly, democratic learning environments (Sriprakash, 2010). As such, 'LCT has been described as a traveling policy, transferred from country to country in the developing world to hopefully solve such historically intractable issues as poverty and political authoritarianism, to increase levels of foreign investment or to extend democratization' (Schweisfurth, 2011). However, Tabulawa (2003) presents an alternative view of the widespread implementation of LCT in developing countries.

Developing countries, as well as more developed countries in the Eastern world, have long been known to follow a TCT didactic approach to education, emphasizing knowledge to be imparted, remembered and then applied. The assessment system also focuses on examining the discrete knowledge and skills and all students have to pass through rigid tests to move on to the next level of education. However, from the 1980s and particularly the 1990s, LCT as a notion originated from the West has been legitimized by government policies to be promoted in educational reforms in many developing countries (Black et al., 1993, in O'Sullivan, 2004; Brodie et al., 2002). There have been many concerns and arguments over the appropriateness of LC for developing countries where the social and cultural values, educational traditions, and available resources are so different from the West. DarlingHammond (1997, cf. Brodie et al., 2002) argues that LCT aiming for integrated curricula, active in-depth learning, appreciation for diversity, collaborative group learning, and individualized teaching, etc., requires substantial school restructuring and management, more open space, rich resources and smaller classes. O'Donoghue (1994) does not think those of discovery learning, activity-based learning and integrated curricula are appropriate for the developing world as they presuppose small classes, rich resources, capable teachers who do not exist.

Similarly, Guthrie (1990) also challenges the appropriateness of those LCT for the developing world. He argues for the TCT approach, which is believed to be more suitable for contexts where resources are limited and teacher professional capability is low. Tabulawa (2003) notes that the current curricular reforms in many African countries (Botswana, Namibia and South Africa) which try to make LCT their official pedagogy in schools are a result of the ideological influence from the West, particularly from Britain over many years of colonialism. However, there are also studies from developing countries that show some degree of teaching effectiveness after adopting a more LCT (Brodie, et al., 2002).

The problem is that learning does not occur in a vacuum. Contexts at all levels, from the immediate classroom to the school culture, from the community where the school locates to as large as the country, influence directly or indirectly what and how teachers teach, hence, what and how children learn in the classroom. The culture of teaching and learning is shaped by the accumulation of historical, cultural, economic and political factors that often cannot be duplicated in any other country in the world (Frisby, 1997). In this sense, any teaching approach will have to be adapted to meet the unique context where teaching takes place and effective methods and techniques can only grow from within that context to accommodate to both the small and large cultures (Holliday, 1999) or 'micro' and 'macro' cultures (Alexander, 2000) rather than being simply transplanted. 
So far, very little research has been conducted to reveal how much of the ideology is implemented in the classrooms. And of the limited research carried out, it has been shown that while, in general, teachers were enthusiastic about the new curriculum and intended to implement LCT practices in their classrooms, LCT ideas were not very much implemented. O'Sullivan (2004) studied 145 unqualified primary teachers within a three-year in-service training program to examine to what extent an LCT curriculum introduced by the Namibian government was implemented in the specific Namibian context. The study found that those LCT ideas such as caring for individual children and use of discovery learning were either beyond the teachers' capacity or constrained by their teaching conditions with limited time and resources. O'Sullivan concludes that LCT as a notion derived from the West has to be adapted to meet the cultural and educational context and the teachers' professional capability.

In another study in Africa, Brodie et al. (2002) examined how teachers in South Africa had taken up LCT practices regarding both form and substance during and after an in-service teacher training program as such an ideology was also explicitly promoted by the government in the new national curriculum. It was pointed out that resources, tasks, questions, and group work were the forms that might or might not enable the substance of LCT. The extent to which teachers elicited and engaged with learners' ideas and interests to develop new ideas and meanings was the substance of LCT. Data were collected over 3 years (1996-1998) using both classroom observations and teacher interviews. The findings showed that only four teachers out of eighteen took up both the forms and substance of LCT, eleven took up only the forms without the substance, and three took neither the form nor the substance. Nevertheless, most teachers attempted to develop alternatives to TCT practices; they tended to move between TCT and LCT practices and developed hybrid teaching styles. The study revealed that how to engage with learners' ideas in teaching was not only difficult to define but also difficult to implement as it required more awareness, experience and effective strategies on the part of the teacher.
A study by Croft (2002) in Malawi examined 15 lessons taught by 5 experienced lower primary teachers in three under-resourced schools in rural Southern Malawi. The study aimed to find out what were considered to be good practices and what good teachers were capable of doing in those impoverished contexts. What was found significant about the lessons was that 11 out of 15 employed songs which seemed to have an important role in making the lessons LCT. Several functions of songs were identified for the primary classrooms studied. Apart from enjoyment, songs also encouraged comprehension and production of language and contributed to classroom management. At a deeper level, songs invoked a sense of community and while singing, all children had to subject their desires to the communal good. In a teaching context with extremely large classes-over 100 and 200 children, without a proper classroom, there was little room for individualism, little room for social contact with the teacher, or physical movement. Songs were found to have helped build a positive relationship between the teacher and the children, giving children a sense of belonging and a sense of security in addition to the content of learning. Although the techniques may not be usefully generalizable for other developing countries where the traditions and context vary, an important implication drawn from the study is that effective teaching techniques can take advantage of the cultural traditions and best maximize learning in the specific context. To summarise, the studies reviewed show that implementing LCT ideologies in developing countries is far more complicated than what the government or proponents expect or think. To a large degree, a gap exists between the espoused ideology and the classroom practices of the teachers. The authors have all stressed the importance of taking into account the local context, such as teacher factors, resources, and cultural traditions when trying to implement LCT. The studies suggest that LCT will need to be modified to take on local features which best encourage learning within that context. In other words, teachers in different contexts may produce a combined version of LCT with both Western features and local features where the context permits.

LCT cannot dislodge TCT practices (Chisholm, et al., 2000; Jansen, 1999; Taylor and Vinjevold, 
1999). In a qualitative study involving eighteen participants from nine schools over three years, Brodie, et al., (2002) conducted class observations with teachers implementing learner-centered activities. They explored whether teachers adopted the form rather than the substance of LCT and to do this, they developed the concepts of forms that were categories like groupings, tasks, and activities. Substance included ways teachers elicited, constructed and developed understanding; ways learners asked questions and how teachers responded to help them develop their thinking. For instance, they observed activities like group works, but save for the physical classroom arrangement; it was noticed that teaching remained very directive and focused on content. Teachers did not allow opportunities for the facilitation of their students' construction of knowledge. They did not consider students' interests, prior knowledge, experiences and aptitude (APA, 1997). The conclusion they drew was that teachers predominantly embraced the form rather than the philosophy of the LCT.

Though teachers are trained to use LCT in classrooms to align with international policy imperatives (Malawi Government, 2000), there is evidence that LCT has not been implemented in classrooms (Moloi, et al., 2008; O'Sullivan, 2004; Taylor and Vinjevold, 1999; Vavrus, 2009). Research in classroom instruction shows the persistence of TCT practices (Hardman, et al., 2008). Mtika (2008) carried out a qualitative study involving four trainee teachers in their second year of teacher training practice and their supervisor. The researcher conducted interviews, class observations and studied the novices' critical incident logs related to LCT. The researcher equally found that LCT teaching was not implemented in classrooms. In their interviews, research participants ascribed their varying degrees of application of LCT to the teacher education system, the student teacher's stance, the school culture, and the National Curriculum. Trainee teachers declared that they were taught to use LCT, but their lecturers used the transmissive approach and lacked practice in LCT activities. Furthermore, the school culture where they were placed was teacher-oriented and trainees had to fit in and adopt the dominant practices for peer acceptance.
The secondary school curriculum was congested and examination-oriented. Both novices and trained teachers had to face the challenge of implementing LCT in an educational system based largely on rote learning. Those teachers equally encountered resistance from learners not used to LCT. Since supervisors remained only temporarily with novices, LCT values and beliefs acquired on teacher education gradually disintegrated and disappeared as student teachers became teachers. Though there is a need to be cautious about a study with four novice teachers, these findings resonate with the discourse that certain pedagogical and theoretical concepts promoted in teacher education are not appropriated by trainees or else are not fitted to the system (Zeichner and Tabachnik, 1981). Likewise, LCT was unsuccessful in Lesotho. Moloi, et al., (2008) suggest that the student teachers' professional training may not have prepared them to deal with problems likely to emerge when teachers use LCT in contexts molded by TCT culture. The researchers evoke the possibility that teachers may not have put in enough effort or else have underestimated the value of group work, altogether a consequence of being underprepared for LCT. In a phenomenological study, Mohammed and Harlech-Jones (2008) reported that professionally trained teachers in Pakistan could not apply the LCT they learned because of the reality of schools. Teachers claimed they got no support from school managers who did not encourage thinking of intellectual quality, who demanded that teachers follow directives, cover the syllabus, use tasks in textbooks and produce results. The researchers believe that reforms in developing countries fail because reformers do not understand the realities of lives \& professional environments of implementers.

What is consistent in studies where LCT has failed is the range of material constraints identified. First, these are limited resources at both school and national level. To some researchers, LCT approaches presuppose the availability of a specially designed environment with space and resources (O'Donoghue, 1994). All schools are not equally endowed and lack of facilities can be a strong inhibitor. These can be infrastructure, class size, or teaching materials (Mohammed and Harlech-Jones, 2008; Urwick and Junaidu, 1991). 
Consequently, failure to take the realities of education systems at the classroom level into account is often cited as an explanation (Schweisfurth, 2011). O'Sullivan (2002) showed how an LCT curriculum project in Namibia failed because policy documents did not take the realities of the teachers' workplace into account and because the model was a top-down decision. Poor teacher training is another hurdle. Expecting teachers to create an LCT environment when they have not been exposed to an LCT may be unrealistic (Brodie, et al., 2002; O'Sullivan, 2004). Research in teacher training in six sub-Saharan countries shows replication of didactic teaching and learning patterns from tutor to teacher trainee to pupil (Akyeampong, et al., 2013). The multiplier effect works where tutors with little or no school experience transmit content knowledge to very large classes of teacher trainees who repeat the pedagogical pattern as teachers in schools to their pupils. Some studies point to reflective practice as the mediating tool for teachers in the transition, but this is, for some, a new way of working that must be learned (Kanu, 1996).

The repercussion effect of high-stakes examinations is equally seen as one major obstacle (Kok-Aun, et al., 2003; George and Lubben, 2002). When students' life chances depend on examinations that test students' ability to reproduce a fixed body of knowledge, classrooms become TCT. However, this argument is contested by other researchers who claim that in LCT classrooms, learners achieve the learning outcomes more frequently and to a higher standard than those in TCT courses (Fink, 2003; Nelson, 2010; Blumberg, 2009). SSS in Mauritius have the material facilities expected of a secondary school and teachers have complete autonomy in their classrooms. One common feature with sub- Saharan countries would probably be the absence of inservice training.

Studies of classroom reform in the global South highlight the need for a more contextualized base for change (Nakabugo and Sieborger, 2001; Sriprakash, 2010; Croft, 2002; Thomson, 2013). Studies in South Africa show that western models of change founded on conditions of teacher agency do not work (Johnson, et al., 2000). What the researchers suggest is attempting small steps at a time and recognizing the 'adjustments teachers can make within the systems in which they find themselves, whilst not denying the need for wider change' (Johnson, et al., 2000). Similarly, a study on LCT in Tanzania (Vavrus, 2009) shows that despite their training, teachers face many difficulties in implementing constructivist teaching and learning in their classrooms. The researcher's conclusion as a participant observer is that it might have been more effective to find ways to improve the quality of TCT rather than trying to replace it. She adds that more contingent constructivism, adapted to the material conditions, local traditions and cultural politics of teaching in Africa, could be more helpful. Thomson (2013), who conducted a small research project in Nigeria on LCT practice, also concludes that cultural translation is important when school contexts are different. He proposes a model where LCT is introduced on a small scale, is adapted to the culture of new audiences and is communicated in a dialogue that respects their conception of the world.

\section{LCT in the Developed World}

The central tenets of LCT views lie in the respect for children's natural interests, their natural developmental stages, learning through experience and discovery, recognizing the function of play in learning, and individual differences of each child. These ideas were revisited, reformulated, and further developed by later writers such as Dewey, Piaget, Vygotsky, Bruner, Donaldson and many others in the 20th century. Dewey (1956) likened this new approach to education to the Copernican revolution. He states:

In traditional education, the center of gravity is outside the child. It is in the teacher, the textbook, anywhere and everywhere you please except in the immediate instincts and activities of the child himself... Now the change which is coming into our education is the shifting of the center of gravity. It is a change, a revolution, not unlike that introduced by Copernicus when the astronomical center shifted from the earth to the sun. In this case, the child becomes the sun about which the appliances of education revolve; he is the center about which they are organized.

Unlike Rousseau, who saw the education of a child in an ideal and isolated environment virtually with no history and social relationships (Entwistle, 1970), Dewey (1956) believed that schools are necessary arrangements for learning and school 
should not be separated from society. Instead, they should reflect the real life of society. He agrees with Rousseau that children are different from adults and education should meet the needs and developmental stages of children. Still, he disagrees with him on the value of a pedagogy which just stirs up children's interests 'without directing it towards definite achievement' (Dewey, 1956). Dewey argues for a pedagogy which should 'get hold of the child's natural impulses and instincts, and to utilize them so that the child is carried on to a higher plane of perception and judgment, and equipped with more efficient habits; so that the child has an enlarged and deepened consciousness and increased control of powers of action.' Dewey stresses that if such a result is not reached, the play would simply be an amusement to children with no function in promoting educational growth. In other words, learning should not be simply in the form of play but in play which fosters reflection and understanding through scientific inquiry (Alexander, 2000). Dewey believes that children need experience and affection, as well as various activities as conditions for learning. Learning for children is a process of active thinking and problem solving (Dewey, 1956).

About the teacher's roles in LCT, Dewey insists that learning should be directed and it should not be left to the child to grow out of his free will. For Dewey, the central question of education is how to take hold of the child's interests and give them direction. 'Through direction, through organized use, they tend toward valuable results, instead of scattering or being left to merely impulsive expression' (Dewey, 1956). Dewey further argues that the development of the child and the implementation of the curriculum should not be viewed as opponents to each other. He warns teachers to guard against the danger with this 'new education' to simply 'let children think things out for themselves without supplying any of the environing conditions which are requisite to start and guide thought. Nothing can be developed from nothing' (Dewey, 1956). For Dewey, it is the child, not the curriculum, that should be at the center of the school.

The claims made by Rousseau, Froebel and Dewey that all children follow a natural sequence of development were further intensified by Piaget.
As a result of extensive experiments and tests, he maintained that children's cognitive development follows four biologically based phases, with each representing a different way of achieving material and rational thought (Turner, 1975; Wood, 1998). The major implication is that the effectiveness of teaching depends on children's readiness to assimilate and accommodate new information. Until the child is ready, it is futile to try to teach. Piaget's works led to the initial formation of the constructivist theory. According to Piaget, children acquire an understanding of the world about them primarily by analyzing their actions upon the world, not by imitation or memorization. However, these factors make contributions (Piaget, 1970). In other words, every learner constructs his or her knowledge by actively making sense of the world around him/ her instead of receiving ideas from a teacher or an authority complete and correct. Learning is an internal and personal process largely obtained from first-hand experiences and communication with other people (Selley, 1999). Therefore, each individual is regarded as an active agent in his learning environment (Turner, 1975) and he constructs new knowledge based on what is already known (Marshall, 2000).

Although Piaget accepts that social experiences and inter-personal communication are important factors for children's cognitive development, they play a rather limited role in his theory as they are conditioned by children's readiness at a particular stage of cognitive development (Wood, 1998). In contrast to Piaget's concept of the isolated individual learner, both Vygotsky and Bruner offered a way of conceptualizing the learning process in a social context, adding an interactive dimension to effective learning. For Vygotsky, the child is not an isolated learner in a world of objects but an active discoverer or participant in a world full of other people with whom he/she interacts to gain experiences and understanding of the world around him/her (Cameron, 2001). Therefore, Vygotsky is often associated with the socio-constructivist theory (Wood, 1998, Cameron, 2001). Vygotsky $(1962,1978)$ emphasizes interaction and engagement with learning tasks in a social context through a language based on the concept of 'Zone of Proximal Development (ZPD). 
In his words, this means 'the discrepancy between a child's mental age and the level he reaches in solving problems with assistance' (Vygotsky, 1962). He states that 'with assistance, every child, can do more than he can by himself - though only within the limits set by the state of his development'. That is to say; learning can best be achieved through the dynamic interaction between the teacher and the learner and between learners. With the teacher's help through questions and explanations or with more capable peers' support, the learner can move to a higher level of understanding with extended skills and knowledge. Through discussion with otherswhere ideas are shared, challenged, negotiated, and justified-new levels of conceptual understanding can be reached (Edwards and Mercer, 1987; Vygotsky, 1978). The implication of Vygotsky's ZPD is that the teacher plays a crucial role in helping the child learn by providing a bridge between what is known and what is to be learned instead of leaving the child alone to figure things out for himself. Children should be given opportunities to actively participate and contribute to their learning guided by the teacher and gradually take on more responsibility for their learning (Wood, 1998). Bruner (1977), along with Vygotsky, stressed the importance of teacher's roles in children's learning and the nature of interaction in the learning environment. He coined the term 'scaffolding' to illustrate that the tasks of adults are to assist children's understanding across the zone of proximal development through carefully structured learning tasks and the use of language.

By 1940, the ideals of progressive education under the influence of Froebel and Dewey became prevalent in the rhetoric of American education (Ravitch, 1983, cf. Alexander, 2000), which focused on identifying the needs of the individual child and constructing educational contexts which supported individual interests by identifying children's differences with a curriculum designed to meet the natural order of the development of the child (Vadeboncoeur, 1997). The main principles were summarised by Kliebard (1986, cf. Vadeboncoeur, 1997) as follows: 'The aim of Progressive Education is the freest and fullest development of the individual, based upon the scientific study of his physical, mental, spiritual, and social characteristics and needs.' Based on these principles, teachers had to learn to struggle between the old-fashioned, subject-centered, authoritarian traditional school and the modern, child-centered, flexible, democratic, progressive school. The Progressive Education Association was formed in 1919 with the sole purpose of applying the theories of Dewey in advancing educational reform (Pulliam and Van Pattern, 1995). Dewey's influence on American education brought fundamental changes in the way education was conceived. There emerged new thoughts about schooling and new patterns of classroom life (Darling, 1994), with public schools extended to nearly all Americans (Lawrence, 1952).

The influence of LCT on British education was, for a long time, rather limited. It became popular during the 1920s to 1930s in infant education under the influence of the Froebel Society and Dewey's writings (The Open University, 1984). Still, it was not until the 1960s that the philosophy of LCT was publicly endorsed by official reports in Britain of which the best known are Primary Education in Scotland or the Primary Memorandum (SED, 1965) which claimed to be very much based on Piaget's works, and Children and their Primary Schools or The Plowden Report (CACE, 1967), which was said to be influenced more by ideas from Rousseau, Dewey and Vygotsky. The latter contains the well-known rubric; at the heart of the educational process lies the child. These two official documents noted above were considered landmarks in the development of LCT in Britain (Darling, 1994).

Even though progressive education became prevalent in rhetoric, a gap between public rhetoric and classroom practice was identified (Alexander, 2000). One of the studies done by Cuban in 1993 examining constancy and change in American classrooms from 1880-1990 found that TCT practices remained robust despite several reforms, particularly in secondary schools. However, a small number of elementary classrooms were identified as developing some LCT practices in terms of using group work and allowing children the freedom to move around in the classroom but not in terms of joint decision-making about methodology or activities. In general, 'the teacher remains in control of knowledge production allowing only limited flexibility in working arrangement' (Cuban, 1993, 
cf. Brodie, et al., 2002). In a comparative study on primary education in five countries, Alexander (2000) identified some elements of LCT in American classrooms with more differentiated groupings and tasks. However, it was also found that as teachers interact with groups and individuals more than with the whole class, they lost contact time with the rest of the class for those periods.

Moreover, American and British lessons were rather loosely structured, with children spending quite a lot of time waiting for teachers' attention as individuals. For every child attended to, there were others who received no attention in a teacher-pupil one-to-one tuition. As a result, individualism had led to complex attempts to deliver instruction on an individual basis through multiple targeted learning tasks and complex group strategies. Hawkins (1985) states that what is most disheartening is that test scores showed that academic achievements declined for students from all socio-economic levels and parents from all socioeconomic groups started trying to send their children to private schools as public education was perceived as public bad.

During the 1960s, 1970s, and 1980s in England, LCT or progressive education becomes the primary speak in the public language of primary education (Alexander, 1995). However, when we examine the actual implementation of LCT and its effectiveness in Britain from the 1930s to 1970s, it is quite surprising that LCT in its pure form was implemented to a fairly limited extent (Alexander, 1984). Alexander (2000) concludes that in English primary classrooms. However, there is a lot of talking going on in classrooms by both teachers and children, its function is seen as primarily social rather than cognitive, and as helpful to learning rather than as fundamental to it'. Several studies carried out in England (Bennett, 1976; Galton, et al., 1980; Aitkin, et al., 1981), using various research methods from questionnaire surveys to classroom observations, found that only a very small percentage of the teaching investigated seemed to belong to the most progressive and the rest was either mixed or largely traditional with the conclusion that progressive teaching is less prevalent than has hitherto been supposed' (Bennett, 1976).
Similarly, Galton et al.'s (1980) study found that individualized teaching resulted in only very limited interaction time between the teacher and each child and the promotion of inquiry or discovery learning appeared almost nonexistent. Also, children were seen sitting in groups but often doing their work. The study found that teachers were neither progressive nor traditional. Simon (1981), based on a review of several studies carried out to assess the effectiveness of LCT, concluded that there was little evidence thereof any fundamental shift either in the content of education or in the procedures of teaching and learning, in the sense that didacticism still largely prevails'. Even Plowden itself had found barely 10 percent of schools that conformed to its full vision (Simon, 1981; Alexander, 2000). In summary, LCT has never been fully implemented despite the rhetoric and it has always had its detractors.

When Margaret Thatcher's Conservative Government was elected in 1979, moves towards strengthening central control of the curriculum and weakening teacher autonomy were well underway (Alexander, 1984; Pollard, et al., 1994), leading to the change tide in education. The requirement of the 1988 National Curriculum challenged classroom procedures which had been promoted during the 1960s and suggested a return to the basics with a more didactic approach to education (Simon, 1994) even though there was no real shift away from didacticism in practice but more so rhetorically. This change of tide was signaled clearly by the Department of Education and Science (DES) in 1981 that the school curriculum is at the heart of education (DES, 1981, cf. Alexander, 1984). LCT was equated with low expectations, undemanding teaching and under achievement according to research studies done during the 1970s, 1980s and early 1990s (Alexander, 2000). Alexander et al. (1992) advised a move towards subject-based teaching and more wholeclass teaching with the benefits of sustaining good order and ensuring clear purpose and concentration of learning.

The introduction of the national curriculum marked an abrupt change of direction in education by the British government from centering on the child to centering on the curriculum. Raising standards across the whole curriculum became the main concern. Along 
with the new curriculum, the separation of literacy and math began to be instigated to ensure the basics were attended to. A whole package of assessment targets was developed for each key stage. All these were based on the assumption that school education had lost touch with 'the real world' (Darling, 1994: vii), unable to produce the right product needed for the economic and technological development. The introduction of the reform was also based on studies of what had happened in Eastern countries such as China and Japan in their high ranking in the international league tables to succeed in school math teaching. Whole class teaching was thus given more value (Alexander, 2000). It is believed that both the educational processes and products need to be improved through a system of attainment targets and a testing system for all students and LCT and practices were seen as defective in helping students achieve high standards to meet the needs of the rapid social and economic development. At present, the National Curriculum, Standards of attainments, assessment and tests, and school League tables have occupied the rhetoric of school Education in England and Wales.

America is also turning away from LCT to give more concern to students' academic achievements. According to Alexander (2000), in the last two decades of the twentieth century, there was an obvious increase in state and federal intervention in educational matters in the United States in terms of attainments achieved by students. The first wave of educational reform to raise standards began in 1983, signaled by the report A Nation at Risk (National Commission on Excellence in Education, 1983). It sets out six goals for the year 2000 to raise standards. This was said to be the most comprehensive attempt at systemic educational reform to that date. The report attributed the educational problems to low academic standards and poor quality of instruction. Solutions from the top-down by the government required improvement by raising achievement standards. These reform efforts targeted an increase in the number of math and science classes, stiffer high school graduation requirements, tougher qualifications and requirements for teachers, increased frequency of testing and assessment of students, etc. (Lambert and McCombs, 1997). By the late 1990s, national assessments were strengthened with particular attention to reading and writing (Alexander, 2000). As the educational system in the United States has been a decentralized one, each state was to develop its tests to measure progress towards the state-level standards concerning the national standards. However, the lesson that seems to be learned by educationalists and policy-makers is that solutions to solve educational problems need to help every student succeed to the highest level possible, both academically and non-academically (Lambert and McCombs, 1997). The result was that throughout the 1990s, LCT was challenged in countries like the UK and the US, and there has been a move back to traditional whole-class teaching (Alexander, 2003).

\section{Conclusion}

LCT is a traveling policy endorsed by international agencies, national governments, and local innovators. As a globally traveling policy and practice, prescriptions and innovations regarding LCT are often found in contexts where it is culturally new and where the realities of educational governance and resources for schools have not historically accommodated it. Learner-centered teaching (LCT) has been a recurrent theme in many national educational policies in the global South and has had wide donor support through aid programs and smaller projects and localized innovations. However, the history of the implementation of LCT in different contexts is riddled with stories of failures, grand and small. Though there are several successful LCT projects, these are too few compared to the magnitude of the failures of the approach in developing countries. In a number of these countries, attempts at transforming traditional classrooms into LCT classrooms have failed. In a recent analysis of the research on LCT implementation, it was evident that the history of the implementation of LCT in different contexts is riddled with stories of failures, grand and small. Across a wide range of developing country contexts, the reports of tissue rejection as teachers and learners struggle to make the paradigm shift far outnumbered the stories of successful transitions from the pedagogies in place towards LCT. I would look towards a more hopeful and holistic version of LCT, which builds on existing pedagogical practices 
rather than attempting (fruitlessly) to usurp them. But the learner needs contextualizing not just in their classroom but in wider national development needs and an increasingly important global context. In this, a globalized, bird's-eye view is certainly of value, but it needs to be offset with local understandings.

\section{References}

Adesoji, Francis A. "Students' Ability Levels and their Competences in a Self-Directed Problem-Solving Task." IFE Journal of Curriculum Studies and Development, vol. 1, no. 1,1995 , pp. 55-61.

Agbayewa, J.O. "The Effects of Enhanced ProblemSolving Instructional Strategy on Students' Concept Learning in Secondary School Physics." Research in Curriculum Studies, vol. 1, no. 1, 1996, pp. 43-46.

Aitkin, M., et al. "Teaching Styles and Pupil Progress: A Re-Analysis." British Journal of Educational Psychology, vol. 51, no. 2, 1981, pp. 170-186.

Akinbobola, A.O. "Effects of Cooperative and Competitive Learning Strategies on the Performance of Students in Physics.” Journal of Research in Education, vol. 1, no. 1, 2004, pp. 71-75.

Akyeampong, Kwame, et al. "Improving Teaching and Learning of Basic Maths and Reading in Africa: Does Teacher Preparation Count?" International Journal of Educational Development, vol. 33, no. 3, 2013, pp. 272282.

Alexander, R.J. Primary Teaching. Cassell, 1984.

Alexander, Robin, et al. Curriculum Organisation and Classroom Practice in Primary Schools: A Discussion Paper. Department of Education and Science, 1992.

Alexander, Robin. "Talk in Teaching and Learning: International Perspectives." New Perspectives on Spoken English in the Class. Qualifications and Curriculum Authority, 2003, pp. 27-37.

Alexander, Robin J. Culture and Pedagogy: International Comparisons in Primary Education. Blackwell, 2000.

Barrett, Angeline M. "Beyond the Polarisation of Pedagogy: Models of Classroom Practice in
Tanzanian Primary Schools." Comparative Education, vol. 43, no. 2, 2007, pp. 273-294.

Bennett, Neville. Teaching Styles and Pupil Progress. Harvard University Press, 1976.

Black, Harry, et al. School Improvement in the Developing World: An Evaluation of the Aga Khan Foundation Programme. Scottish Council For Research In Education, 1993.

Blumberg, Phyllis. Developing Learner-Centred Teaching: A Practical Guide for Faculty. Wiley, 2009.

Brock-Utne, Birgit, and Halla Holmarsdottir. "Language Policies and Practices in Tanzania and South Africa: Problems and Challenges." International Journal of Educational Development, vol. 24, no. 1, 2004, pp. 67-83.

Brodiea, Karin, et al. "Forms and Substance in Learner-Centred Teaching: Teachers' Takeup from an In-Service Programme in South Africa." Teaching and Teacher Education, vol. 18 , no. 5 , 2002, pp. 541-559.

Bruner, J.S. "Early Social Interaction and Language Acquisition." Studies in Mother-Infant Interaction. Edited by H.R. Schaffer, Academic Press, 1977, pp. 271-289.

Cameron, Lynne. Teaching Languages to Young Learners. Cambridge University Press, 2001.

Chisholm, Linda, et al. South African Curriculum for the Twenty First Century. Report of the Review Committee on Curriculum 2005, 2000.

Croft, Alison. "Singing Under a Tree: Does Oral Culture Help Lower Primary Teachers to be Learner-Centred?" International Journal of Educational Development, vol. 22, no. 3-4, 2002, pp. 321-337.

Cuban, Larry. How Teachers Taught: Constancy and Change in American Classrooms 1880-1990. Teachers' College Press, 1993.

Darling, John. Child-centred Education and its Critics. Paul Chapman Publishing Ltd., 1994.

Darling-Hammond, Linda. "The Quality of Teaching Matters Most." Journal of Staff Development, vol. 18, 1997, pp. 38-41.

Dewey, John. The Child and the Curriculum. University of Chicago Press, 1956. 
Dewey, John. The School and Society. University of Chicago Press. 1956.

E205 Conflict and Change in Education: A Sociological Introduction. The Open University Press.

Edwards, Derek, and Neil Mercer. Common Knowledge: The Development of Understanding in the Classroom. Methuen, 1987.

Entwistle, Harold. Child-centred Education. Routledge, 1970.

Fink, L. Dee. Creating Significant Learning Experiences: An Integrated Approach to Designing College Courses. Wiley, 2003.

Frisby, Craig L. "Contextual Factors Influencing the Classroom Application of Learner-Centred Principles." How Students Learn: Reforming Schools through Learner-Centred Education. Edited by N.M. Lambert and B.L McCombs, American Psychological Association, 1998, pp. 61-79.

Galton, Maurice J., et al. Inside the Primary Classroom. Routledge and Kegan Paul, 1980.

George, June M., and Fred Lubben. "Facilitating Teachers' Professional Growth through Their Involvement in Creating Context-Based Materials in Science." International Journal of Educational Development, vol. 22, no. 6, 2002, pp. 659-672.

Guthrie, G. "In the Defense of Formalistic Teaching." Teachers and Teaching in the Developing World. Edited by V. Rust, and P. Dalin, Garland, 1990, pp. 219-232.

Guthrie, Gerald. The Progressive Education in Developing Countries: In Favour of Formalism. Springer, 2011.

Hardman, Frank, et al. "Changing Pedagogical Practice in Kenyan Primary Schools: The Impact of School-Based Training." Comparative Education, vol. 45, no. 1, 2009, pp. 65-86.

Hardman, Frank, et al. "Pedagogical Renewal: Improving the Quality of Classroom Interaction in Nigerian Primary Schools." International Journal of Educational Development, vol. 28, 2008, pp. 55-69.
Harley, Ken, et al. "The Real and the Ideal: Teacher Roles and Competences in South African Policy and Practice." International Journal of Educational Development, vol. 20, no. 4, 2000, pp. 287-304.

Hofstede, Geert. Culture's Consequences: Comparing Values, Behaviours, Institutions, and Organisations Across Nations. Sage, 2003.

Holliday, A. "Small Cultures." Applied Linguistics, vol. 20, no. 2, 1999, pp. 237-264.

Jansen, J. "A Very Noisy OBE: The Implementation of OBE in Grade 1 classrooms." Changing Curriculum: Studies on Outcomes-Based Education in South Africa. Juta, 1999.

Johnson, Sally, et al. "Teacher Development and Change in South Africa: A Critique of the Appropriateness of Transfer of Northern/ Western Practice." Compare: A Journal of Comparative and International Education, vol. 30, no. 2, 2000, pp. 179-192.

Kanu, Yatta. "Educating Teachers for the Improvement of the Quality of Basic Education in Developing Countries." International Journal of Educational Development, vol. 16, no. 2, 1996, pp. 173-184.

Kanu, Yatta. "Teachers' Perceptions of the Integration of Aboriginal Culture into the High School Curriculum." Alberta Journal of Educational Research, vol. 51, 2005, pp. 50-68.

Kliebard, Herbert M. The Struggle for the American Curriculum 1893-1958. Routledge. 1986.

Lambert, Nadine M., and B.L.McCombs. "Introduction: Learner-Centred Schools and Classrooms as a Direction for School Reform." How Students Learn: Reforming Schools through Learner Centred Education. American Psychological Association, 1998, pp. 1-22.

Lawrence, Evelyn. Friedrich Froebel and English Education. University of London Press, 1952.

Learner-centred Psychological Principles: Guidelines for School Redesign and Reform. American Psychological Association, 1993.

Marshall, Hermine H. "Teaching Educational Psychology: Learner-centered and 
Constructivist Perspectives." How Students Learn: Reforming Schools through LearnerCentred Education. Edited by N.M. Lambert, and B.L. McCombs, American Psychological Association, 2000, pp. 449-461.

Mohammed, Razia Fakir, and Brian Harlech-Jones. "The Fault is in Ourselves: Looking at Failures in Implementation." Compare: A Journal of Comparative and International Education, vol. 38, no. 1, 2008, pp. 39-51.

Moloi, Francina, et al. "Free but Inaccessible Primary Education: A Critique of the Pedagogy of English and Mathematics in Lesotho." International Journal of Educational Development, vol. 28, 2008, pp. 612-621.

Mtika, Peter, and Peter Gates. "Developing LearnerCentred Education among Secondary Trainee Teachers in Malawi: The Dilema of Appropriation and Application." International Journal of Educational Development, vol. 30, no. 4, 2010, pp. 396-404.

Mtika, Peter. Teaching Practice as a Component of Teacher Education in Malawi: Activity Theory Perspective. University of Nottingham, 2008.

Nakabugo, Mary Goretti, and Rob Sieborger. "Curriculum Reform and Teaching in South Africa: Making a Paradigm Shift?" International Journal of Educational Development, vol. 21, no. 1, 2001, pp. 53-60.

Nelson, Craig E. "Dysfunctional Illusions of Rigor: Lessons from the Scholarship of Teaching and Learning." To Improve the Academy, vol. 28, no. 1, 2010, pp. 177-192.

Nykiel-Herbert, Barbara. "Mis-Constructing Knowledge: The Case of Learner-Centred Pedagogy in South Africa." Prospects, vol. 34, 2004, pp. 249-265.

Ozga, Jenny, and Robert Jones. "Travelling and Embedded Policy: The Case of Knowledge Transfer." Journal of Education Policy, vol. 21, no. 1, 2006, pp. 1-17.

O’Donoghue, Thomas. "The Need for Educational Reform and the Role of Teacher Training: An Alternative Perspective." International Journal of Educational Development, vol. 14, no. 2, 1994, pp. 207-210.
O'Sullivan, Margo. "Lesson Observation and Quality in Primary Education as Contextual Teaching and Learning Processes." International Journal of Educational Development, vol. 26, no. 3, 2006, pp. 246-260.

O'Sullivan, Margo. "Reform Implementation and the Realities within which Teachers Work: A Namibian Case Study." Compare: A Journal of Comparative and International Education, vol. 32, no. 2, 2002, pp. 219-237.

O'Sullivan, Margo. “The Reconceptualisation of Learner-Centred Approaches: A Namibian Case Study." International Journal of Educational Development, vol. 24, no. 6, 2004, pp. 585-602.

Piaget, J. "Piaget's Theory." Carmichael's Manual of Child Psychology. Edited by P.H. Mussen, Wiley, 1970.

Pollard, Andrew, et al. Changing English Primary Schools: The Impact of the Education Reform Act at Key Stage One. Cassell, 1994.

Pulliam, John D., and James Van Patten. History of Education in America. Merrill, 1995.

Ravitch, Diane. The Troubled Crusade: American Education 1945-1980. Basic Books, 1983.

Schweisfurth, Michele. Learner-Centred Education in International Perspective: Whose Pedagogy for Whose Development?. Routledge, 2013.

Schweisfurth, Michele. "Learner-Centred Education in Developing Country Contexts: From Solution to Problem?" International Journal of Educational Development, vol. 31, no. 5, 2011, pp. 425-432.

Selley, Nick. Art of Constructivist Teaching in the Primary School: A Guide for Students and Teachers. Routledge, 1999.

Serbessa, Derebssa D. "Tension between Traditional and Modern Teaching-Learning Approaches in Ethiopian Primary Schools." Journal of International Cooperation in Education, vol. 9, no. 1, 2006, pp. 123-140.

Simon, B. "The Primary School Revolution: Myth or Reality?" Research and Practice in the Primary Classroom. Routledge, 1981.

Simon, Brian. "Primary Practice in Historical Context." Thinking through Primary Practice. Edited by Jill Bourne, Routledge, 1994. 
Srinivasan, Mini. Confronting $\quad$ Stereotypes. $\quad$ Vadeboncoeur, Jennifer A. "Child Development and 2012, http://www.india-seminar. the Purpose of Education: A Historical Context com/2012/638/638_mini_shrinivasan.htm

Sripakash, Arathi. "Child-Centred Education and the Promise of Democratic Learning: Pedagogic Messages in Rural Indian Primary Schools." International Journal of Educational Development, vol. 30, 2010, pp. 297-304.

Sternberg, Robert J. "Culture, Instruction and Assessment." Comparative Education, vol. 43, no. 1, 2007, pp. 5-22.

Tabulawa, Richard. "International Aid Agencies, Learner-Centred Pedagogy and Political Democratisation: A Critique." Comparative Education, vol. 39, no. 1, 2003, pp. 7-26.

Taylor, Nick, and Penny Vinjevold. Getting Learning Right. Report of the President's Education Initiative Research Project, Joint Education Trust, 1999.

Thomson, Paul. "Learner-Centred Education and Cultural Translation." International Journal of Educational Development, vol. 33, no. 1, 2013, pp. 48-58.

Toh, Kok-Aun, et al. "Teaching, Teacher Knowledge and Constructivism." Educational Research for Policy and Practice, 2003, pp. 195-204.

Turner, J. Cognitive Development. Methuen \& Co., 1975.

Urwick, James, and Sanusi Usman Junaidu. "The Effects of School Physical Facilities on the Processes of Education: A Qualitative Study of Nigerian Primary Schools." International Journal of Educational Development, vol. 11, for Constructivism in Teacher Education." Constructivist Teacher Education: Building a World of New Understandings. Edited by V. Richardson, Routledge, 1997.

Van Harmelen, Ursula. "Is Learner Centred Education, Child Centred?" Journal for Educational Reform in Namibia, vol. 8, 1998.

Vavrus, Frances. "The Cultural Politics of Constructivist Pedagogies: Teacher Education Reform in the United Republic of Tanzania." International Journal of Educational Development, vol. 29, 2009, pp. 303-311.

Vygotsky, L.S. Mind in Society: The Development of Higher Psychological Processes. Harvard University Press, 1978.

Vygotsky, Lev S. Thought and Language. The MIT Press, 1962.

What Makes Teachers Tick?: A Policy Research Report on Teacher Motivation in Developing Countries. VSO, 2002.

Wood, David. How Children Think and Learn. Blackwell, 1998.

World Declaration on Education for All. World Conference on Education for All, UNESCO, 1990.

Zeichner, Kenneth M., and B. Robert Tabachnik. “Are the Effects of University Teacher Education 'Washed Out' by School Experiences?' Journal of Teacher Education, vol. 32, no. 3, 1981, pp. 7-11. no. 1, 1991, pp. 19-29.

\footnotetext{
Author Details

Dr. Rajendra Kumar Shah, Associate Professor, Tribhuvan University (Sanothimi Campus), Bhaktapur, Nepal, Email ID: Drrajendrakumarshah@gmail.com
} 